\title{
Todellinen elämä: Bergson ja koettu luonto
}

\author{
JAN-IVAR LINDÉN
}

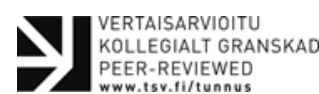

\begin{abstract}
ABSTRAKTI Bergsonin elämänfilosofia liittyy laajaan suuntaukseen, joka syntyi biologian mullistuksien myötä 1800-luvun loppupuolella (Friedrich Nietzsche, Wilhelm Dilthey, Menyhert Palágyi, Ludwig Klages, Max Scheler, Georg Simmel, William James...). Sikäli kuin naturalismi tulkitaan tämän päivän keskustelussa usein yksipuolisesti materialismiksi, elämänfilosofia voi antaa toisen kiinnostavan näkökulman ihmisen asemaan luonnossa. Suuntaus on tässä suhteessa vahvasti vaikuttanut fenomenologisiin teorioihin subjektin ruumiillisuudesta ja yleensäkin embodiment-käsitteeseen. Artikkelin tarkoitus on valaista filosofisen psykologian ja luonnonfilosofian suhdetta Bergsonin tuotannossa, temaattisesti syventää tätä suhdetta sekä historiallisesti ja ontologisesti taustoittaa Bergsonin filosofiaa, muun muassa suhteessa hänen edeltäjänsä Félix Ravaissonin aristotelismiin.
\end{abstract}

Ehkä teorian on rajoituttava ainoastaan tiettyyn näkökulmaan, jotta se olisi tieteellinen, siis jotta se antaisi yksityiskohtien tutkimiselle täsmällisen suunnan. Mutta todellisuus, johon jokainen teoria avaa osittaisen näkökulman, ylittää kaikki näkökulmat. L'évolution créatrice, s. 85.

...ylimielisellä nöyryydellään järkemme haluaa julistaa lopullisesti tuntevansa ainoastaan suhteellisen, absoluuttisen jäädessä sen vastuualueen ulkopuolelle: tämä alustava julistus antaa sille mahdollisuuden soveltaa tavanomaista ajattelun metodia estoitta, ja viitaten verukkeena siihen, että absoluuttinen ei kuulu sille, ratkoa absoluuttisesti kaikkea.

L'évolution créatrice, s. 48-9.

\section{Johdanto}

Elämänfilosofiseksi kutsuttu aatesuuntaus voimistui varsinkin biologian mullistuksien myötä 1800-luvun puolessa välissä. Käsite on kuitenkin laaja. Friedrich Nietzsche mainitaan usein suuntauksen edelläkävijänä, tärkeäksi hahmoksi katsotaan Henri Bergson, mutta myös Alfred North Whiteheadia kutsutaan usein elämänfilosofiksi. Ilya Prigoginillä on yhteyksiä tähän tieteenteoreettisesti tärkeään suuntaukseen. Saksassa Wilhelm Dilthey on keskeinen lähde, myös siksi, että hän yhdistää elämänfilosofisia ja tietoteoreettisia aineksia varsinkin kirjoituksissaan ymmärryksen (Verstehen) suhteesta selitykseen (Erklären). Sosiologian ja filosofian rajamaastossa liikkuvat ajattelijat kuten Max Scheler, Georg Simmel ja Walter Benjamin kuuluvat monessa mielessä elämänfilosofian piiriin, samoin varsin selväs- 
ti Ludwig Klages ja hänen oppi-isänsä fyysikko Menyhert (Melchior) Palágyi. William James on pragmatismissaan omaksunut monia elämänfilosofian keskeisiä ajatuksia. Yhteiseksi nimittäjäksi tällaisessa vivahteikkaassa kentässä voisi nostaa ajatuksen, että elämä on kokemuksen edellytys eikä niinkään sen objekti. Seuraavassa temaattisessa tulkinnassa tämä on keskeinen lähtökohta: siis ajatus siitä, että luonto elämänä on kokemuksessa ja tiedossa voimakkaasti vaikuttava tekijä. Kaikkea tiedollista tarkastelua edeltää osallisuutemme todellisuudesta. Artikkeli valaisee Bergsonin suhdetta niin edeltävään traditioon kuin hänen aikalaisiinsa, sekä osoittaa miten Bergsonin aiheet ovat osittain samansuuntaisia kuin myöhemmässä ranskalaisessa, ruumiillisuutta korostavassa fenomenologiassa.

Elämä edellytyksenä on kokemuksessamme ja tiedossamme vaikuttava luonto, eikä siis hyödyllinen objekti tieteellisessä, teknisessä tai muussa toiminnassamme. Tällaisen elämän tiedostaminen vaatii aina osallisuutta, eikä se seuraa objektivoivaa tiedon mallia, joka perustuu ajatukseen ulkoapäin toimivasta subjektista. Ajatus tiedostavan subjektin kuulumattomuudesta tutkimuskenttäänsä (Descartesin Arkhimedeen piste luonnollisen ja historiallisen maailman ulkopuolella) perustuu oletukseen, että osallisuus estää objektiivisen tiedon, kun taas vastakkainen näkemys lähtee siitä, että osallisuus mahdollistaa ei ainoastaan kokemuksen vaan myös tiedon. Ei kuitenkaan ole täysin selvää miten meidän pitäisi ymmärtää Bergsonin filosofiaa tässä valossa. Muistiteorian kautta Bergson nimittäin haluaa osoittaa miten kokemuksessamme on aina myös puhtaasti henkinen taso.

Matière et mémoire -teoksessa hän puhuu muistista, joka ei ole ruumiiseen liittyvä tottumus (mémoire-habitude) vaan puhtaasti henkinen souvenir pur. Souvenir-sanaa käytetään ranskan kielessä usein monikossa (souvenirs) ja silloin se tarkoittaa henkilön muistikuvia tai muistoja. Bergsonilla termi on substantiivi, joka korostaa henkistä kykyä palauttaa mennyt mieleen menneenä ja ilman hyötyhakuisuutta. Englanniksi vastine olisi recollection, kreikaksi anamnesis. Puhdas mieleenpalautus olisi tarkka suomenkielinen vastine souvenir pur -käsitteelle, mutta jos pidetään mielessä tämän muistitoiminnon puhtaasti henkinen luonne Bergsonilla, voi tietysti myös puhua muistosta ja muistamisesta. Kokemuksen toinen tekijä on Bergsonin mukaan puhdas havainto (perception pure), joka on nimenomaan hyötyyn, intresseihin, ruumiiseen ja aineelliseen maailmaan liittyvä toiminto. Seuraavassa aiheena on tämän jaottelun suhde Bergsonin L'évolution créatrice -teoksessa esittämään luonnonfilosofiaan. Bergsonin eri näkemykset myös heijastuvat hänen käsityksessään älystä ja ymmärtämisestä. Kyse on Bergsonilla aina myös elämän ja tiedon välisestä suhteesta ja tämä ilmenee nimenomaan psykologian ja luonnonfilosofian läheisessä suhteessa. Samalla näiden välillä on myös tietty jännite, joka näkyy selvästi vertailtaessa Matière et mémoire -teosta myöhempään L'évolution créatrice -teokseen. Tämä johtuu osittain siitä, että ensinmainitussa kirjassa Bergson valaisee elämän ja tiedon suhdetta havainnon ja puhtaan muistin välisenä vuorovaikutuksena, kun taas jälkimmäisessä, luonnonfilosofisessa teoksessa äly ja intuitio tarjoavat vastakkaisia mahdollisuuksia ajattelulle.

\section{Tausta}

L'évolution créatrice -teoksessa Bergsonin keskeinen aihe on elämän voima (élan vital) inhimillisessä tiedossa ja tietoisuudessa. Tällainen näkökulma on tyypillinen elämänfilosofialle reaktiona uuden ajan tieto- ja tieteenteoriassa vallinnneeseen mentalistiseen suuntaukseen. Mistä sitten tässä mentalistisessa traditiossa on kyse? Usein puhutaan myös subjektifilosofiasta tai tietoisuusfilosofiasta (Bewußtseinsphilosophie) ja pidetään Descartesia suuntauksen avainhahmona. Descartes on äärimmäinen esimerkki ajattelijasta, jolle elämän käsite on täysin vieras. Eläimet ovat hänelle koneita, mutta ei niinkään siitä syystä, että hän olisi halveksinut eläimiä, vaan tietoteoreettisista lähtökohdista johtuen. Myös ihmisen keho on kone. Elämälle ei ole todellista sijaa Descartesin ajatusmaailmassa, koska hänelle tämä käsite liittyi aristoteeliseen ajatukseen sielusta elämän periaatteena. Tästä katsantotavasta Descartes halusi nimenomaan päästä eroon tulkitessaan 
sielun cogitoksi, eli tietoisuudeksi, ja ruumiin koneeksi. Hegel käyttää Descartesista ilmaisua "' der wahrhafte Anfänger der modernen Philosophie'”' ja yhdistää siten merkitykset aloittaja ja aloittelija (Anfänger, Hegel 1986, 123). Tietoisuutta korostavassa suuntauksessa kyse ei ole ainoastaan kartesiolaisesta rationalismista, vaan yleisemmästä taipumuksesta tulkita maailmaa tiedostavan subjektin tutkimuskenttänä. Subjekti lähtökohtana on myös saman aikakauden empiristisessä traditiossa lähinnä itsestäänselvyys. Descartesin tavoin myös John Locke asettaa kysymyksensä sisäisen minuuden näkökulmasta eli subjektista lähtien. Juuri tämä jako luo tietoteoreettisen ongelman, miten yhteys sisäisen ja ulkoisen maailman välillä on mahdollinen. Tämä ongelma vaikuttaa vielä David Humen skeptisismissa, jossa kyseenalaistaminen edellyttää epäilevää mieltä.

Epistemologia on usein ollut eräänlaista teoreettista sillanrakentamista, josta yritettiin päästä eroon jo 1800-luvun alussa. Myös Hegelin henki (Geist) on subjektiivinen taho, mutta ei enää yksilöllisen minuuden muodossa. Hegel laajentaa äärimmäisen rationalismin nimissä subjektivisuuden käsitettä siten, että se kattaa itse todellisuuden. Schelling ehdotti toisenlaista vaihtoehtoa korostaessaan luontoa tiedon kantavana tasona, joka juuri ei-tiedostettuna mahdollistaa tiedon ja sivistyshistorian. Kummallekaan heistä, kuten saksalaiselle idealismille yleensä, ei enää Immanuel Kantin jälkeen ollut mahdollista ajatella todellisuutta vanhemman metafysiikan tavoin oliona itsessään, ilman ajattelijan oman kokemuksen luonteen ja määräytyneisyyden huomioonottamista. Samalla he halusivat päästä eroon Kantin antimetafyysisesta asenteesta. Sekä Hegelin että Schellingin ratkaisu oli hyväksyä se osa kantilaisesta taustasta, joka kiisti mahdollisuuden puhua todellisuudesta ilman sen ottamista huomioon, että todellisuus ilmenee meille tietyllä tavalla ja siitä syystä myös kaikissa ilmenemismuodoissaan riippuu meidän edellytyksistämme. Hegelillä nämä edellytykset yhdistyvät varsinkin historiaan, Schellingillä sekä historiaan että loogisesti ei-redusoitavissa olevaan luontoon. Molemmissa tapauksissa olemme osallisina todellisessa tapahtumassa. Myös Marxin hegeliläisyys ilmaisee omalla tavallaan samansuuntaista näkökantaa.

Myöhemmin 1800-luvun loppupuolella syntyi toisenlainen reaktio tietoisuuskeskeiselle suuntaukselle epistemologiassa ja yleensä filosofiassa. Tämä uusi naturalistinen suuntaus kritisoi idealistista filosofiaa ja asetti sen vastakohdaksi luonnontieteellisen maailmankuvan. Evoluutiosta tuli keskeinen käsite myös filosofiassa. 1900-luvulla niin kutsuttu evolutionaarinen epistemologia on myöhäinen ja vielä tänäänkin voimakkaasti vaikuttava haara tästä ajatussuunnasta. Ongelmana tällaisessa teoriassa kuitenkin on, että se jollain tavalla jättää huomioimatta Kantin jaottelun tiedon ulottuvissa olevan (ilmenevä, fenomenaalinen maailma) ja tiedon ulottumattomissa (Ding an sich) olevan välillä - mutta ei tietoisesti saksalaisen idealismin tavoin, vaan sen sijaan käyttämällä tiettyä osa-aluetta jo tutkitusta (fenomenaalisesta) maailmasta perustana itse tiedon selittämisessä. Näin syntyy ongelmallinen kehä, jossa tiedon edellytykset selitetään tiedon objekteilla. Joissakin tapauksissa tällainen biologismi yhdistetään materialismiin, mistä syntyy toinen ongelma siinä määrin kuin elävä luonto vaikuttaa olevan jotakin muuta kuin silkkaa materiaa.

Mikäli haluamme ymmärtää Bergsonia ja elämänfilosofista traditiota yleensä, on tärkeää nähdä, että naturalismi ei suinkaan velvoita materialismiin. Elämän käsite tarkoittaa nimenomaan luontoa, joka ei ole samaistettavissa materiaan. Jos elämä vaatii edellytyksekseen myös aineellisia seikkoja, se on toinen asia. Elämänfilosofia korostaa, että inhimillinen tieto, tiede, kokemus ja kulttuuri yleensä ovat luonnon ilmentymistä meissä. Tässä mielessä elämä on koettu luonto. Bergsonin tausta on tässä osittain Maine de Biranista juontuvassa ranskalaisessa luonnonfilosofian ja filosofisen psykologian traditiossa, mutta sillä on myös Bergsonille varsin tärkeän edeltäjän Félix Ravaissonin kautta suhde Schellingin filosofiaan. Varsinkin filosofisen psykologiansa ja luonnonfilosofiansa kautta Ravaisson on keskeinen hahmo aristotelismin paluussa 1800-luvun Ranskassa (Ravaisson 1838 ja varsinkin Ravaisson 1837-46). Ravaisson kuitenkin käyttää sekä aristoteelisia että schellingiläisiä argumentteja uudessa kontekstissa vapautuakseen edeltäjänsä Maine de Biranin ensin 
varsin empiristisestä ja sitten pikemmin uuskartesiolaisesta, voluntaristisesti sävytetystä filosofiasta (volo, ergo sum) - samalla kuitenkin Biranin keskeisiä ajatuksia hyödyntäen. Ravaissonin tausta on luonnollisen organisaation analyysissa ja sen suhteessa tottumukseen (habitude), joka nimenomaan todellisena organisaationa eroaa tieteen välineellistämistä lainalaisuuksista. Sama aihe esiintyy myös Bergsonilla, varsinkin teoksessa Matière et mémoire, mutta myös ontologian kannalta kiinnostavammassa L'évolution créatrice -teoksessa.

\section{Puhdas havainto ja puhdas muisti}

Matière et mémoire -teoksessa Bergson kritisoi samanaikaisesti niin idealistisia,positivistisia, spiritualistisia kuin materialistisia katsantotapoja. Usein pääkritiikki kohdistuu näissä suuntauksissa joko avoimesti tunnustettuun tai taustalla piilevään dualismiin. Samalla sekä materia että henki esiintyvät tärkeinä käsitteinä myös Bergsonin omassa havaintoteoriassa, ja teoksen alkusanoissa hän näyttää jopa puolustavan tiettyä dualismia. Tulkitsijalle tämä on haaste, varsinkin kun Bergsonin käyttämä käsitteistö on joskus varsin erikoista. Havainnon materiaalisia esineitä (olioita) kutsutaan esimerkiksi "'kuviksi"” (images) ja mieleenpalautuksen sisältöjä "muistikuviksi" (souvenirs-images). Materiaalisia kuvia koskien Bergson kuitenkin perustelee sanavalintansa selvästi. Hän haluaa käyttää havaitsemiskentästä ja sen ilmiöistä nimitystä, joka on neutraali suhteessa jakoon kuvitelman, tai representaation (représentation), ja itse kohteen (chose) välillä. Kuva ei siis ole objekti eikä myöskään subjektiivinen representaatio (kuvitelma), vaan "'kuva joka on olemassa itsessään"” (une image qui existe en soi, Bergson 1990, 2). Bergsonin ajatus liittyy tässä yleisempään suuntaukseen havaintoteoriassa, joka vastustaa ideaa siitä, että havainto olisi jollain tavalla sisäinen vastine ulkoiselle objektille (veil of perceptions). Bergsonin sanavalinnan onnistuneisuudesta voidaan kiistellä, mutta keskeinen idea on kiinnostava eli käsitys siitä, että puhdas havainto (perception pure) - millä Bergson tarkoittaa havaintoa ilman puhtaan muis- ton (souvenir pur) osuutta - ei merkitse lisätasoa ympäröivässä materiaalisessa (kuva)maailmassa, vaan päinvastoin rajoittaa tämän maailman. Rajoitus riippuu havaitsevasta kehosta ja sen kiinnostuksesta, joka perimmiltään on vitaalinen ja alun perin tarpeisiin liittyvä toiminto. Ero puhtaan havainnon ja havaitun maailman välillä ei siis ole kvalitatiivinen vaan fokusoinnista riippuva. Havainto ei lisää mitään vaan se on suppeampi versio annetusta tilanteesta. Havainto on toisin sanoen erikoisilmiö toiminnallisessa kentässä, jossa liikkuva, elävä ja tunteva olio toimii keskuksena ja rajoittaa dynaamista maailmaa tietystä näkökulmasta (Bergson 1990, 19). Ajatus on hyvin samansuuntainen kuin Martin Heideggerin käsitteissä In-der-Welt-sein (maailmassaolo) - jolla on suora vastine Bergsonin ilmaisussa un tout solidaire (Bergson 1990, 41) - ja Erschlossenheit, joka Heideggerilla tarkoittaa nimenomaan, että maailma avautuu meille (wird erschlossen) samanaikaisen sulkeutumisen kautta (schliessen tarkoittaa sulkemista, Heidegger 1986, varsinkin luvut 3 ja 6). Voisi sanoa, että tämä on eletyn määräytymisen perusluonne. Molemmat ajattelijat myös korostavat havainnon toiminnallisuutta (käytäntöön liittyvää luonnetta) ja kritisoivat siten ideaa siitä, että havainto olisi kontemplatiivista. Samankaltainen näkemys löytyy myös William Jamesilta. Kyse ei ole subjektin spontaanisuudesta kantilaisessa mielessä vaan nimenomaan kiinnostuneesta toiminnasta. Usein toiminta jää virtuaaliseksi ja silloin on kyse ainoastaan havainnosta. Sikäli kun toiminta myös vaikuttaa kehossa alustavana motorisena liikkeenä, havaintoon liittyy samalla tunto (affect). Bergsonille (ja myös William Jamesille, mutta ei Heideggerille) tyypillistä on kuitenkin naturalistinen taipumus asettaa ihminen luonnolliseen kontekstiin, jossa toiminnallisuus on ontologisesti keskeistä juuri eläimellisyydestä johtuen.

Dualismin ongelma on selittää, miten täysin erilaiset substanssit (ulottuva ja ajatteleva olio) voivat olla vuorovaikutuksessa. Miten ulottuva olio voi näyttäytyä ajattelevassa oliossa ja millä tavalla ajatteleva olio voi olla yhteydessä ulottuvaan olioon? Välttääkseen tämän ongelman, Bergson puhuu itsessään kvalitatiivisesta maail- 
masta, jossa ei ole eroa primaari- ja sekundaarikvaliteettien välillä. (Vanhemmassa filosofisessa traditiossa on erilaisia kuvauksia ensisijaisista kvaliteeteista, joiden keskeinen idea on, että ne olisivat olioissa itsessään esimerkiksi kokona, hahmona, liikkuvuutena, kun taas toissijaiset kvaliteetit kuten väri, tuoksu, maku ja ääni riippuisivat havaitsevasta subjektista.) Bergsonin mukaan havainto on sen sijaan tietynlainen ote toiminnallisesta kentästä, jonka kautta tietyt aspektit korostuvat, tulematta silti sisäisiksi. Koko jako sisäisen ja ulkoisen välillä johtuu havaitsevan eläimen liikkuvasta kehosta, joka havaintokeskuksena muuttuu vähemmän kuin ympäristö ja samalla tapahtumaketjujen ruumiillisista vaikutuksista johtuen ilmenee henkilökohtaisena tuntona. Liikkumisesta riippuva raja ulkoisen ja sisäisen välillä ei kuitenkaan osoita, että havaitun maailman ja havaintosisältöjen välillä olisi kvalitatiivinen ero (Bergson 1990, 19-21).

Tältä osin Bergson vaikuttaa melkein pragmatistilta, joka korostaa olioiden ja esineiden käytännöllistä luonnetta (esineiden ollessa pragmata sanan kirjaimellisessa, käyttöä korostavassa mielessä). Matière et mémoire -teoksen toinen pääaihe vie kuitenkin suuntaan, missä myös kontemplaatiolle löytyy sijaa. Muisti, varsinkin puhtaana muistona (souvenir pur), edustaa jotakin muuta kuin vitaalista käytäntöä. Mieleen palautuva on nimittäin jo mennyt ja ei enää salli toimintaa. Puhdas muistaminen, yhtä hyvin kuin puhdas havainto, ovat Bergsonin mukaan kuitenkin äärimmäisyyksiä, jotka todellisessa kokemuksessa kietoutuvat toisiinsa. Puhtaan havainnon kohdalla mieleenpalautusta mahdollistaa tietty määräytymättömyys (indetermination), joka liittyy hermoston luonteeseen. On olemassa mikroorganismeja, joissa sensorinen ja motorinen eivät eroa toisistaan, vaan jokainen virike (kosketus) aiheuttaa heti reaktion. Monimutkaisempien organismien kuten nisäkkäiden suhteen tilanne on kuitenkin toinen, koska hermostolla on toimintakeskus, aivot, jolloin virike ja vastaus loitontuvat toisistaan ja toiminta ei ole samalla tavalla välitöntä. Bergson näkee tässä ruumiillisen perustan souvenir pur -muistille ja sen tuomalle mahdollisuudelle vähentää reaktioiden välittömyyttä. Täl- laista aivotoiminnallista avoimuutta hän nimittää "määräytymättömyyden vyöhykkeeksi" (zone d'indetermination). Aivot eivät kuitenkaan selitä niiden mahdollistamia muistikokemuksia. Bergsonin usein siteerattu esimerkki on naula seinässä ja sille ripustettu vaate. Ilman naulaa vaatteen muoto ei olisi samanlainen, mutta se, miten vaate ilmenee, ei kuitenkaan selity naulan kautta (Bergson 1990, 4). Asiaa voisi kuvata myös toisella tavalla: vaikka aivot ovat välttämätön edellytys henkiselle elämälle, ne eivät kuitenkaan selitä henkistä elämää. Esimerkiksi happi ilmassa oli Venäjän vallankumoukselle välttämätön edellytys, mutta ei varmastikaan selitä kyseistä murrosta, eikä siis ole riittävä edellytys. Hermoston määräytymättömyys on mieleenpalautukselle välttämätön edellytys, mutta mieleenpalautus on henkinen toiminto nimenomaan siitä syystä, että se ei koske läsnäolevan pragmatiikkaa. Tästä henkisestä toiminnosta riippuu myös tahdon mahdollisuus valita vaihtoehtojen välillä. Jos $M a-$ tière et mémoire -teoksesta löytyy dualismia, kyse on tästä asetelmasta, toiminnallisen havainnon ja mieleenpalautuksen suhteesta.

Souvenir pur -muistin kautta Bergson nostaa esille muistitoiminnon, joka helposti jää toissijaiseksi niissä teorioissa, jotka etsivät yleispäteviä muistipiirteitä. Puhdas muisto on nimittäin henkilölle tarjoutuva suhde ainutlaatuisiin tapahtumiin menneisyydessä. Bergson korostaa, että mennyt on yhtä paljon olemassaoleva kuin nykyinen ja tuleva, eikä ainoastaan nykyisyydessä vaikuttavana muistona tai habituaalisena muistina vaan nimenomaan menneenä. Toisin sanoen läsnäolevalla ei ole ontologista etusijaa. Samalla mennyt on olemassa partikulaarisina, hyvin yksilöllisinä muistikuvina, ja siinä määrin kuin Bergsonin käsitys hengestä ja tahdonvapaudesta liittyy tähän muistiin, singulaarinen muistielämys saa tärkeän roolin hänen teoriassaan.

Bergson puhuu kuitenkin myös toisesta muistin muodosta, tottumuksesta (mémoire-habitude), joka suoraan edistää toimintaa siten, että habituaaliset dispositiot edesauttavat määräytyneisyyttä ihmiseläimen kokemuksessa. Tottumuksen kautta reaktio (organismin vastaus virikkeelle) tulee yhä välittömämmäksi. Tästä syystä Bergson ym- 
märtää habituaalisen muistin materiaalisen maailman jatkeena eli puhtaasti toiminnallisena dispositiona, samalla tavalla kuin puhdas havainto on ainoastaan tietynlainen erikoistapaus materiaalisessa toimintakentässä. Siksi tottumus ei osoita mainittavaa henkistä läsnäoloa tapahtumassa. Ainoastaan puhdas muistaminen on Bergsonille tällainen henkinen toiminto.

Maailma koostuu kuvista ja kuvitelma tai representaatio on tiettyjen kuvien tai aspektien korostamista. Menneisyys ei lakkaa olemasta, kun se ei enää ole läsnäolevaa. Menneisyyteen ei kuitenkaan voi enää vaikuttaa ja se poistuu toiminnallisen tarkkaavaisuuden (attention) kentästä mutta säilyy silti muistikuvina. Nämä muistikuvat eivät ole tottumuksien kaltaisia yleisesti jaettavissa olevia dispositioita vaan yksittäisten hetkien ainutlaatuisia tallenteita. Tälle asetelmalle - kuva, kuvitelma, muistikuva ja tottumus - rakentuu Bergsonin teos Matière et mémoire.

\section{Alitajunta ja mieleenpalautus}

Matière et mémoire -teoksen mukaan menneet kokemukset ovat tiedostamattomina läsnä souvenir pur -muistissa. Jos tiedostamaton psyyke olisi ainoastaan tällainen, vaikuttaisi siltä kuin tiedostamaton olisi vain menneen säilymistä eikä mitään muuta. Silloin Bergson olisi jättänyt pois ne aspektit tiedostamattomassa, jotka liittyvät viettien dynamiikkaan tai ainakin rajoittanut muistikuvien muokkauksen siihen vaikutukseen, joka läsnäolevassa hetkessä tulee havainnon toiminnallisuudesta. Asia on kuitenkin monimutkaisempi. Mennyt nimittäin vaikuttaa myös habituaalisen muistin kautta ja myös tämä on tiedostamatonta. Bergsonilla on kuitenkin Matière et mémoire -teoksessa taipumus tulkita tottumus mekaaniseksi toiminnoksi eikä hän sanottavasti käsittele vuorovaikutuksia puhtaan muistamisen ja habituaalisen muistin välillä. L'évolution créatrice -teoksessa asetelma on toinen, mutta myös siinä Bergson erottaa uutta luovan elämänvoiman (élan vital) orgaanisesti määräävistä dispositioista, jotka toki vaikuttavat luonnossa, mutta lähinnä jonkinlaisena mekaanisena jäänteenä. Silloin elämänvoima ei ainakaan voi olla - kuten
Ravaissonilla - habituaalinen organisaatio, mutta ei myöskään menneisyyttä mieleen palauttavan puhtaan muistin laajempi versio.

On siis vaikea nähdä, miten Matière et mémoire -teoksen käsitejako perception pure / souvenir pur pitäisi ymmärtää suhteessa luonnonfilosofiseen jakoon ponnistelevan elämänvoiman ja jäykän organisaation välillä. Herää kysymys: onko tottumus todella täysin erilainen mekaaninen muistitoiminto verrattuna henkiseen puhtaaseen muistiin? Jos näin on, tottumuksella ei enää ole yhteyttä niihin muistoihin, jotka yksittäisinä säilyvät ja toiminnan salliessa voivat palautua mieleen. Usein korostetaan häiriön ja virheiden roolia oppimisprosesseissa. Jos myös häiriötä mahdollisesti seuraava tauko ja siinä vapautuva tila mieleenpalautukselle on kokemuksessamme tärkeä, voidaan kyseenalaistaa Bergsonin jyrkkä erottelu puhtaan muistin ja tottumuksen välillä. Hetkellisillä muistikuvilla olisi vaikutusta tottumuksiimme ja ne olisivat habituaalisen dynamiikan kanssa vuorovaikutuksessa.

Puhtaassa muistissa henkilön menneisyys on tiedostamattomana läsnä. Normaalisti sillä ei ole mahdollisuutta palautua mieleen toiminnassa, joka perustuu kiinnostuneeseen havaintoon. Siinä missä häiriötilanteessa jää aikaa muuhun kuin vain häiriön poistamiseen jatkuvalla toiminnalla, muistikuvat sen sijaan voivat palautua mieleen ja myös sekoittua havaintoon ja toimintaan. Mieleenpalautus tulee mahdolliseksi häiriön tuottaessa keskeytystä toiminnassa tai yleensä toimintavaatimuksien hellittäessä. Bergsonin tärkeä esimerkki on uni, joka kytkeytyy Matière et mémoire -teoksessa ihmisen reflektoivaan kykyyn. Muuten Platonia vahvasti kritisoiva Bergson antaa tässä uudenlaisen merkityksen anamnesis-teorialle, joka on hänelle eräänlaista oneirista mieleenpalautumista. Tahdonvapaus selittyy tästä henkisestä aineksesta. Bergson näkee siis tiedostamattoman muistitason hengen lähteeksi ja siksi ei ole yllättävää, että hän tulkitsee unen keskeiseksi henkiseksi toiminnoksi. Juuri unessa ja hereillä tapahtuvassa uneksimisessa käytännön vaatimukset jäävät toissijaisiksi ja muistikuville syntyy siten tilaa kokemuksessa ja myös mahdollisuuksia vaikuttaa myöhempään havaintoon ja 
käytäntöön. Tässä mielessä uni ja uneksiminen ovat reflektoivalle oliolle varsin tärkeitä. Marcel Proust on ammentanut paljon tästä näkemyksestä, joka eroaa Sigmund Freudin teoriasta (Traum als Wunscherfüllung) juuri refleksiivisyyden korostamisessa. Filosofiassa Gaston Bachelard on tutkinut samankaltaisia aiheita.

On selvää, että Bergsonin ajatusmaailma liittyy hänen aikansa yleiseen kiinnostukseen tiedostamatonta kohtaan, jonka Freud teki tunnetuksi, mutta joka oli ollut jo aikaisemmin läsnä myös Eduard von Haartmannin teoksissa, Carl Gustav Caruksen schellingiläisyydessä sekä Bergsonille tärkeässä Ravaissonin filosofisessa psykologiassa ja luonnonfilosofiassa (Hartmann 1869; Carus 1846). Vaikka Bergsonilta löytyy viittauksia Freudin teoksiin, hän ei kuitenkaan hyödynnä Freudin viettiteoriaa Matière et mémoire -teoksessa esittämässään tulkinnassa mieleenpalautuksesta. Sen sijaan luonnonfilosofinen teos L'évolution créatrice on tältä osin kiinnostavampi, koska tiedostamaton dynamiikka on siinä keskeisessä asemassa ponnistelevan elämänvoiman (élan vital) muodossa. Tulkitsijalle jää kuitenkin haasteeksi yhdistää Bergsonin luonnonfilosofia hänen psykologiaansa.

\section{Filosofinen psykologia ja luonnonfilosofia}

Jos Matière et mémoire -teoksessa materiaalinen maailma on kvalitatiivinen toimintakenttä, josta havaitseva olio on osallisena, myöhemmässä L'évolution créatrice -teoksessa Bergsonin käsitys materiasta näyttää muuttuneen. Ponnisteleva elämänvoima on luonnonfilosofiassa keskeinen ja materiasta tulee tämän ponnistelun vastus tai este. Materia ei siis enää ole annettu dynaaminen toimintakenttä, vaan toissijaista suhteessa elämänvoimaan. Vaikuttaa melkein jopa siltä, että materia ymmärretään epämääräiseksi toiminnan vastavoimaksi. Tulkitsijalle on vaikeaa yhteensovittaa näitä käsityksiä, siis materiaa kuvainnollisena toimintakenttänä (Matière et mémoire) ja materiaa vastuksena (L'évolution créatrice).

Siinä missä Ravaisson kritisoi edeltäjänsä Maine de Birania, Bergson vaikuttaa osittain hyväksy- vän Maine de Biranin voluntarismin. Biranin teoria spontaanista ponnistelusta (effort) saa jatkeen Bergsonin käsitteessä ponnisteleva elämänvoima (un effort plus qu'individuel, Bergson 1994, 88). Matière et mémoire -teoksessa tahto on kuitenkin mieleenpalautuksesta riippuva, melkeinpä reflektoiva toiminto. Miten muistikuvat sitten vaikuttavat havaintoon ja toimintaan? Voisiko mieleenpalautuksen muistikuva olla samanlainen vaikutin kuin ulkoiset virikkeet havainnon toimintakentässä? Virike voisi joko olla materiaalinen kuva (image) tai henkinen muistikuva (souvenir-image). Vielä kiinnostavampaa tämä olisi, jos muistikuvat myös vaikuttaisivat tottumuksiin - niitä ylläpitäen, muokaten tai joskus jopa heikentäen.

Vaikea kysymys koskee siis sitä, miten toinen muistin muoto, eli tottumus, pitää ymmärtää suhteessa puhtaaseen havaintoon ja puhtaaseen muistoon. Miten tottumuksen dispositiot yleensä säilyvät ja miten ne eri tilanteissa taas aktualisoituvat? Eikö olisi luontevaa ajatella, että nimenomaan puhtaan muistikyvyn muistikuvat olisivat tässä jollain tavalla osallisia? Bergson puhuu muistikuvista habituaalisen organisaation ohjaavana toimintona (assosiaatio), mutta pitää kuitenkin kahden muistin periaatteellisesta erosta kiinni. Tässä olisi mahdollisuus ajatella toisin. Dispositio on - kuten Aristoteles on syvällisesti osoittanut - ontologisesti hyvin kiinnostava eikä suinkaan vain mekaaninen vaikutin toiminnassa. Dispositio on olemassa myös silloin, kun se ei aktuaalisesti toimi. Miten se siis silloin on olemassa? Bergson, joka muuten hyvin selkeästi osoittaa aivokeskeisen reduktionismin ongelmia, ei kuitenkaan tässä hyödynnä omia argumenttejaan. Tämä on hämmästyttävää, ottaen huomioon hänen läheisen suhteensa Félix Ravaissoniin, jonka teoksissa tottumus on keskeinen sekä luonnonfilosofinen että psykologinen käsite.

Matière et mémoire -teoksessa tottumus esiintyy kehon muistina, mutta Bergsonin varsinainen aihe - toisin kuin Ravaissonin - ei ole tämän tason psyykkisten ja ontologisten ulottuvuuksien tulkinta. Varmasti osittain tämä johtuu hänen kriittisestä kreikkalaisen filosofian tulkinnastaan, jossa hän usein hieman ongelmallisella tavalla samaistaa Platonin ja Aristoteleen käsitykset. Tie- 
tyssä mielessä Bergsonin filosofia on eräänlaista käänteistä platonismia, jossa liikkumaton (muuttumaton) on toisarvoista ja prosessi sen sijaan keskeistä (eikä siis suinkaan harhaanjohtavan aistillisen maailman ilmentymä). Siinä missä Ravaisson nimenomaan korostaa Aristoteleen viettiteoriaa ja luonnollisen tapahtuman merkitystä Platonia vastaan, Bergson sen sijaan, hyväksymällä varsin metafyysisen Aristoteles-tulkinnan, usein näyttää katsovan, että Aristoteleen muodot olisivat suoria Platonin ideoiden vastineita. Kuten jo L'évolution créatrice -teoksen nimi ilmaisee, luonto on Bergsonille aina uusien muotojen syntymistä, eli luovaa tapahtumaa. Tässä tapahtumassa luonnolliset muodot ovat sivutuotteita, joiden määräytyneisyys ei ole pysyvää eikä myöskään itse luontoa selittävää. Tämän voisi tulkita tavanomaisena teleologiakritiikkinä, mutta Bergsonin teoria kuitenkin eroaa tällaisesta kritiikistä siinä, että se samanaikaisesti kritisoi sekä mekanistista että teleologista luonnontulkintaa. Molemmat lähtevät nimittäin samasta oletuksesta, jonka mukaan luonto toimisi rakennusmestarin tavoin, mekanistinen näkemys vain korostaa osien välineellisyyttä siinä missä teleologia olettaa, että luonnollisissa konstruktioissa olisi myös tarkoitus, joka antaa toiminnoille päämäärän. Bergson hylkää molemmat näkemykset ja ehdottaa vaihtoehdoksi ponnistelevan elämävoiman käsitettä. Luonto toimii siis ilman päämääriä mutta myös ilman mekanismeja. Jokaisessa tilanteessa syntyy elävälle oliolle tarve edetä mielekkäällä tavalla ja elämävoiman ponnistelu on juuri se innovatiivinen toiminto, joka löytää koko ajan uudistuvissa tilanteissa aikaisemmin tuntemattomia vaihteluita käyttäytymisessä.

\section{Bergson ja vitalismi}

On syytä korostaa, että tämä näkemys ei merkitse vitalismia, jos vitalismi ymmärretään puhtaasti biologisena terminä, jota käytetään mekanistisen ajattelutavan teleologisesta vastakohdasta. Näin käsitettynä vitalismia edustaisi Hans Driesch, jonka omatakeinen tulkinta päämääräsuuntaisista prosesseista, entelekioista, antoi 1900-luvun alkupuolella teleologiakeskustelulle uusia virik- keitä (Driesch 1928). Bergson ottaa kantaa tähän keskusteluun, mutta ei niinkään teleologiaa puolustavana ajattelijana vaan pikemmin antamalla keskustelulle filosofista taustaa. Samalla tavalla kuin teleologisen ja mekanistisen luontokäsityksen tapauksessa, myöskään Bergsonin aikana yleisen lamarckilaisuuden ja weismannilaisen darwinismin kohdalla hän ei asetu kannattamaan vain yhtä puolta. Tietty sympatia sellaista lamarckilaista ajattelua kohtaan, jonka mukaan myös yksilön elämässä vakintuneet ominaisuudet voivat periytyä, kuitenkin selittyy sillä, että Bergsonille elämänvoima on ennen individuaatiota vaikuttava tekijä (Bergson 1994, 87-88). Olisi toki kiinnostavaa tutkia miten tämä ajatus sijoittuu suhteessa keskusteluun siitä biologisesta tasosta, jolla luonnonvalinta tapahtuu (organismi, geenit, ryhmä), mutta tällöin kannattaa pitää mielessä, että nämä teoriat perinnöllisyyden mekanismeista kuitenkin jäävät Bergsonin elämänfilosofian ulkopuolelle siinä määrin kuin kyse on nimenomaan mekanismeista.

Bergsonin kritisoidessa samanaikaisesti sekä teleologista että mekanistista luonnontulkintaa, hänen argumenttinsa ei ainoastaan koske molempien käsityksien taustaa inhimillisessä toiminnassa ja sen intresseissä vaan myös oletettua ideaa siitä, että "kaikki on annettu" (tout est donné), siis joko alulle panevana päämääränä tai määräävinä lainalaisuuksina. Mekanistisen maailmankatsomuksen determinismiä koskien hän mainitsee kuitenkin Hugo de Vriesin teorian äkillisistä muutoksista eli mutaatioista (Bergson 1994, 63-4, 86-7), jolloin syntyy vaikutelma, että tässä kaikki ei nimenomaan ole etukäteen annettua, vaan päinvastoin sattumanvaraisuuksista riippuvaa. Ei kuitenkaan tule täysin selväksi, miten sattuma Bergsonin mukaan suhtautuu uutta luovaan elämänvoimaan.

\section{Luonnon asema kokemuksessa ja tiedossa}

Bergsonin käsitys tiedosta, joka ei rajoitu päämääriä tavoittelevaan ja välineitä käyttävään älyyn, perustuu mahdollisuuksiimme tiedostaa luonnon luovuutta sellaisena kuin se ilmenee 
ihmisen ulottuvissa olevassa elämässä. Hänen kiinnostuksensa biologiaa kohtaan on nähtävä tässä valossa. Tietty ongelma kuitenkin syntyy siitä mittavasta tutkimuksesta, joka toisinaan vie hänet ontologisiin päätelmiin luonnontieteellisen tiedon pohjalta. Nimenomaan tästä on aiheutunut sekaannuksia tulkinnoissa, jotka haluavat nähdä Bergsonin vitalistina biologisessa mielessä. On kuitenkin selvää, että Bergsonin tärkeys ilmenee pikemminkin toisenlaisessa lähestymistavassa, joka tutkii tiedon ja tietoisuuden edellytyksiä siinä koetussa luonnossa, siis elämässä, joka mahdollistaa ihmisen henkisiä toimintoja, tiede mukaanlukien.

Tässä yhteydessä on tietysti todettava myös, että reflektoiva ymmärrys riippuu kaikesta siitä, mitä kokemus on meille antanut. Siihen kuuluu myös kaikki se, mitä eri tieteet ovat tuoneet mukanaan, mikä nykyään on hyvin tärkeä aines myös arkikokemuksessa. Kyse ei siis ole siitä, että esimerkiksi luonnontieteiden saavutukset olisivat vailla tärkeyttä filosofisessa ymmärryksessä, vaan ainoastaan siitä, että tieteellinen tieto on yksi tiedon muoto ja sen objektit enemmän tai vähemmän tosia laajemmassa kontekstissa, joka kattaa paljon enemmän kuin ainoastaan tietynlaisen metodin tutkimuskentän. Tieteen ja tiedon ymmärtämisessä tällainen jo objektivoitu alue ei voi toimia perustana. Kantin kriittinen näkemys siitä, että $a$ posteriorinen ei voi selittää a prioria pätee vieläkin, vaikka a priorisia edellytyksiä ei ehkä enää voi selittää Kantin subjektifilosofian puitteissa. Bergsonin lähestymistavassa kiinnostavaa on nimenomaan se, miten hän tulkitsee luonnontieteellisiä lähteitä toisella tavalla kuin miten niitä kyseisten tieteiden sisällä tulkitaan. Päämääränä ei ole niinkään osallistua luonnontieteelliseen pyrkimykseen määrittää lainmukaisuuksia ja ilmiöitä kokeellisessa tutkimuskentässä vaan pikemmin valaista niin luonnontieteellisen kuin muunkin tiedon avulla inhimillisen kokemuksen perimmäistä luonnetta ja sen todellisia edellytyksiä.

Edeltäjäänsä Ravaissoniin verrattuna Bergson näkee kuitenkin luonnon määräävät dispositiot, siis luonnon organisaation, lähinnä ponnistelevan elämänvoiman sivutuotteena eikä siten hyödynnä tätä edeltävää määräävää tasoa omassa teoriassaan. Hänen käänteinen platonisminsa suuntautuu samalla Aristotelesta vastaan, kun taas aristoteelikko Ravaisson tulkitsee dispositioita ja tottumuksia luovuuden ja myös vapauden olennaisiksi, orgaanisiksi edellytyksiksi eikä suinkaan näiden vastakohdaksi.

\section{Äly}

Toiminta on siis Bergsonille keskeinen puoli havainnossa, mutta puhdas havainto ei ole samaistettavissa tietoisuuteen, joka liittyy puhtaaseen muistiin. Tämä on tärkeää myös siksi, että tieto sisältää eroavaisuuksia, jotka perustuvat tietoisuuden ja havainnon suhteeseen. Kuten filosofisessa traditiossa on ollut tapana, myös Bergson erittelee tiedon muotoja. Äly (josta hän käyttää erilaisia nimityksiä: intelligence, intellect, entendement) on havainnon jatke ja sen erityinen kyky on havainnon tavalla toiminnallinen, mutta se eroaa havainnosta erittelemällä ja määrittelemällä kohteitaan toisella tavalla. Käsitteet korvaavat havainnon kiintopisteet ja äly voi tällä tavalla suunnistaa myös mahdollisissa maailmoissa. Käsite on nimenomaan samankaltaisuutta tai samuutta (konseptuaalista identiteettiä) korostava kielellinen toiminto. Samoin kuin esineelliset kiintopisteet havainnossa myös käsitteet auttavat meitä identifioimaan ilmiöitä ympäristössämme.

Älykäs toiminta voi hyödyllisyyden puitteissa olla hyvinkin etevää, mutta tiedostamatta mistä älyllisesti käsiteltävässä maailmassa on kyse. Tietoisuus, tiedostaminen ja ymmärrys esiintyvät konkreettisessa ihmiselämässä toki yhdessä älyn kanssa, mutta äly itsessään on aivan liian pragmaattinen kyky toimiakseen myös tiedostavana ja ymmärtävänä. Tämä on tausta Bergsonin idealle, jonka mukaan monet teoreettiset ongelmat johtuvat siitä, että käytännölliset intressit, ja niihin soveltuvat käsitteet, vaikuttavat ajatusmaailmassa vielä silloinkin, kun ei enää ole kyse käytännöstä. Tästä aiheutuu joitain ongelmia, mutta Bergsonin ratkaisuehdotus ei kuitenkaan ole Wittgensteinin tavoin ymmärtää filosofia jonkinlaisena käsiteterapiana. 
Bergson turvautuu ajattelun kykyyn ylittää käsitteiden rajoitusmekanismeja. Bergsonin idea filosofisesta intuitiosta on kuitenkin usein ymmärretty väärin. Hän ei suinkaan ole käsitteellistä ajattelua vastaan vaan painottaa ainoastaan, että meillä on luontainen taipumus nähdä kaikki juuri käsitteellisen kyvyn valossa. Ylettyäkseen itse todellisuuteen ajattelun on löydettävä itsestään sellaisia vaikutteita, jotka mahdollistavat alati muuttuvan todellisuuden (durée réelle) ymmärtämisen ilman käsitteille ominaista identiteettiä. Kyse on toisenlaisesta tiedon muodosta kuin määrittelevästä ja vakautta tavoittelevasta tiedosta.

Tästä saa helposti kuvan, että Bergson olisi jollain tavalla mystiikan edustaja. Sellainen tulkinta syntynee osittain nykykielessä niinkin epämääräiseltä vaikuttavasta sanasta kuin "intuitio". Jos intuitiolla tarkoitetaan kykyä välittömästi oivaltaa todellisuuden sisintä luonnetta, jo Bergsonin teoria hengestä ja muistista välittömyyden vastavoimana pitäisi herättää epäluuloja tällaista tulkintaa kohtaan. Samoin voi myös todeta, että Bergsonin hyvin laaja ja syvällinen tuntemus oman aikansa tieteellisistä teorioista puhuu toista kieltä. Irrationalismista ei siis ole kyse vaan pikemmin pyrkimyksestä taustoittaa tiedon ja havainnon toimintakenttää ontologisesti ja hahmotella, millaista käsiteltävän maailman jatkuva tunnistaminen voisi olla: kyse on tavasta lähestyä todellisuutta, mutta ilman systemaattista tavoitetta luoda hyödyllistä teoriaa.

\section{Käsitteet ja välineellinen järki}

Bergsonin filosofialla on yhtymäkohtia myöhemmin 1900-luvulla tärkeään välineellisen järjen kritiikkiin (instrumentelle Vernunft), esimerkiksi Horkheimerin ja Adornon teoksissa. Bergsonin teoria kausaliteetista on myös kiinnostava siinä määrin kuin se osoittaa, miten moderni käsitys syistä ja seurauksista edustaa perimmiltään välineellineellistä näkökulmaa luonnon prosesseihin (interventionistinen kausaliteetti). Modernissa käsityksessä kausaliteetti riippuu samankaltaisuudesta. Vain olettaen, että syy on samanlainen myös toisessa yhteydessä kuin alun perin todetussa, voidaan puhua yleisestä kausaalisesta yhtey- destä syyn ja seurauksen välillä. Bergson kuvailee jopa mekanistista luontokäsitystä tästä näkökulmasta: "Mekanismin periaate on että 'samat syyt tuottavat samoja seurauksia'”. Ilmiöiden homogeenisuus matemaattisissa luonnontieteissä on tässä oiva apuväline.

Syntyy kuitenkin kysymyksiä koskien Bergsonin ideaa siitä, että käsitteellinen identiteetti (samuus) olisi vastine havainnon orientaatiota mahdollistaville kiintopisteille. Aristoteleen käsitys liikkumattomasta ja muuttumattomasta ei suinkaan ole inhimillisen kokemuksen apuväline, vaan päinvastoin annettu pysyvyys todellisuudessa, joka sanelee kokemuksen ja ajattelun mahdollisuuksia. Määräytyneisyyttä on kaikkialla ja toimimme sen puitteissa, myös ajattelussa, koska ajateltava on todellinen noeton. Tämä aristoteelinen näkemys ei kuitenkaan ole ratkaiseva moderneissa luonnontieteissä, joissa tiedeyhteisöllä on aloite määrittelemisessä ja nykyisin pitkälti jopa maailman määräytymisessä.

Durée réelle, eli todellinen jatkumo, on ponnistelevan elämänvoiman leimaama todellisuus eikä kesto vanhemman tradition tarkoittamassa mielessä, siis ei semper idem, alati sama, vaan alati muuttuva. Bergsonin käsitys siitä, että kehitys jatkuvasti luo uusia muotoja, edustaa tiettyä modernia piirrettä siinä määrin kuin luonto esiintyy tässä vailla olemusta aristoteelisessa mielessä. Ominaista Bergsonille on kuitenkin tapa soveltaa tätä näkemystä myös kieleen ja varsinkin sen käsitteelliseen ainekseen.

Bergsonille elämänvoima on tietoa edeltävä mutta tiedossa yhä vaikuttava luonnonvoima. Elämä ei luo rakentamalla ja yhdistelemällä osia suunnitelman mukaisesti vaan eriytymisen kautta (dissociation). Tästä syystä elämänvoima vaikuttaa yhä myös meissä, vaikka meidän (eriytymisen kautta syntynyt) erityispiirteemme ei esimerkiksi hyönteisten tavoin ole vaistomainen vaan älyllinen. Erityispiirteistämme huolimatta elämänvoiman tausta vaikuttaa ja on yhä elämässämme kantava asia, joskin älyn ulottumattomissa. Juuri tämä suhde älyn (intelligence) ja vaiston (instinct) välillä luo ongelmia silloin, kun haluamme ymmärtää luonnollisen todellisuuden vaikutustapaa. Projisoimme nimittäin älyn tarvitsemia 
kiintopisteitä ja tulkitsemme inhimillisen erityispiirteen mukaisesti luonnollista todellisuutta rakennelmana. Tämä on toimintamme kannalta hyödyllinen ja etevyyttä lisäävä strategia, mutta sen kääntöpuolena on, että se samalla heikentää mahdollisuuksiamme ymmärtää luontoa (L'intelligence est caractérisée par une incompréhension naturelle de la vie, mt., 166). Kokemuksessamme on aina epämääräisempi kehys, joka on myös tiedostettavissa mutta vain silloin, kun avaudumme muiden elävien olioiden suuntaan projisoimatta niihin älyn pragmatiikkaa.

Valitettavasti Bergson ei kuitenkaan tarpeeksi syvennä käsitteiden roolia tämänkaltaisessa ymmärryksessä. Hän näyttää ajattelevan, että äly aina "jähmettää" (solidifie) todellisuutta (mt., 46). Sekä havainnon että käsitteellisen ajattelun suhteen voisi väittää, että tässä on esitetty vain pragmaattinen aspekti, joka ei suinkaan merkitse, että asiat ja käsitteet aina esiintyisivät tällaisina pragmaattisina kiintopisteinä. Jotkut muotoilut Bergsonin teksteissä ovat tässä mielessä hankalia, mutta sekä hänen havaintoteoriansa että hänen filosofinen käsitteistönsä näyttävät kuitenkin, että asioilla ja käsitteillä on muitakin kuin ainoastaan pragmaattisia ilmenemismuotoja.

Perinteisempi erottelu älyn (intellectus, Verstand) ja järjen (ratio, Vernunft) välillä sekä esimerkiksi saksalaisen idealismin käsitys spekulatiivisesta (eli heijastavasta) lauseesta olisivat tässä yhteydessä voineet tarjota kiinnostavia näkökulmia Bergsonin intuition käsitteeseen. Vaikuttaa nimittäin siltä kuin käsitteellisyys ei suinkaan olisi ainoastaan adaptiivisen tottumuksen jatke ja pragmaattisen älyn työkalu tai kategoria (Verstandesbegriff), vaan myös looginen toiminto (Reflexionsbegriff), jonka avulla voimme pysähdyttää ajatustottumuksia ja siten syventää kokemustamme myös muulla tavalla kuin välineellisten käsitteiden kautta. Jos älyllisesti muotoutunut tahto on jollain tavalla, kuten Bergson sanoo, synnynnäinen metafysiikkamme, voisi ajatella että vähemmän metafyysisen, mutta filosofisesti reflektoivan ymmärryksen tehtävä olisi nimenomaan valaista, mitkä ne luonnolliset ja historialliset voimat ovat, jotka tässä vaikuttavat. Tällaisessa tulkinnassa ilmenee selvemmin, että Bergsonin joskus hieman ylimalkaiset väitteet älystä eivät niinkään suuntaudu käsitteellistä ajattelua vastaan, joka on tietysti varsin keskeinen ei ainoastaan pragmaattisessa vaan myös reflektoivassa suhtautumisessa. Bergsonin filosofia voi tällöin tarjota hyvinkin ajankohtaisen näkökulman ihmisen rooliin maailmassa ja todellisuudessa. Usein ajatellaan, että vanhempi traditio oli antroposentrinen kun taas uuden ajan mullistukset asettivat ihmisen maailmankaikkeudessa ja luonnossa laajempaan kontekstiin. Tällainen kuvaus on kuitenkin harhaanjohtava siinä, että mekanistinen maailmankuva on nimenomaan antroposentrinen projisoidessaan inhimillistä mekaniikkaa todellisuuteen.

\section{*}

Elämänä luonto on koettu ja kokemus on kokemuksena todellinen. Näin on myös ihmiselämässä, olkoon tuo kokemus sitten toiminnallista, tiedollista tai ymmärtävää. Kuulumme luontoon, ja sekä tomintamme että ajattelumme vaatii tällaista kuuluvuutta, joka on jatkuvasti läsnä historiassamme. Kuuluminen luontoon sitoo meitä, mutta mahdollistavalla tavalla. Olemme evoluution puitteissa saaneet toiminnallisen tilan, jossa voimme navigoida ja edetä mielekkäällä tavalla. Myös tieto perustuu tällaiseen jo annettuun olemassaoloon. Idea kartesiolaisesta Arkhimedeen pisteestä luonnollisen (ja historiallisen) maailman ulkopuolella on Bergsonille vieras, kuten elämänfilosofialle yleensäkin. Bergsonille on ominaista, että hän muistiteoriansa kautta viitoittaa alueen, jossa ihminen on jollain tavalla vapaa vitaalisista toiminnallisista paineista. Syntyykö tästä filosofisesta psykologiasta uudenlainen dualismi, on avoin kysymys. L'évolution créatrice ei anna sellaiselle tulkinnalle tukea, mutta ongelmia syntyy Bergsonin filosofian eri vaiheiden yhteensovittamisessa.

Luonnonfilosofiassa asetelma muuttuu monessa suhteessa. Materian käsite, joka Matière et mémoire -teoksessa tarkoittaa lähinnä todellisuuden toiminnallista tasoa, ja jonka Bergson ymmärtää kvalitatiivisena kenttänä ilman erottelua ensi- ja toissijaisten kvaliteettien välillä, muuntuu L'évolution créatrice -teoksessa yhä enemmän tois- 
sijaiseksi tasoksi, joka edustaa lähinnä ponnistelevan elämänvoiman vastavoimaa. Kummassakaan teoksessa Bergsonin materian käsitteestä ei mitenkään seuraa materialistista luontokäsitystä ja Bergsonin filosofia on siten omiaan osoittamaan ongelmia nykyään niin yleisessä samaistamisessa materialismin ja naturalismin välillä. Toisaalta luovan elämänvoiman vahva korostus loitontaa Bergsonia hänen edeltäjänsä Félix Ravaissonin aristotelismista, jossa luonnon organisaatio (tottumus) ei ole uutta luovan elämänvoiman jähmettynyt sivutuote, vaan elävälle luonnolle luonteenomainen sinnikkäästi muotoja tuottava ja muokkaava toiminto.

Kiinnostavaa tässä yhteydessä on kuitenkin, miten Bergson sekä teoriassaan puhtaasta mieleenpalautuksesta että luonnonfilosofiassaan antaa määräytömättömyydelle tärkeän roolin (zone d'indetermination) ja siten täydentää Ravaissonin ja vanhemman tradition ehkä hieman liiallista määräytyneiden muotojen korostusta. Varsin omaperäinen on myös Bergsonin käsitys unesta ja uneksimisesta refleksiivisyyden perusilmiönä, vaikka tämäkin ajatus kaipaisi täydentävää analyysia viettien ja alitajunnan suhteesta ja alitajunnan roolista tiedossa. Älyn tulkinta kiinnostuneen havainnon jatkeeksi suo kuitenkin mahdollisuuksia käyttää Bergsonin ajatuskulkua myös tällaisessa yhteydessä. Ajoittainen tendenssi nähdä käsitteelisyys jähmeänä toimintona, joka estää todellista ymmärtämistä, ei silloin ole etusijalla. Vaikka tämä piirre toki vaikutti Bergsonilta inspiraatiota saanessa filosofisessa suuntauksessa, voi kuitenkin todeta, että Bergsonin koko tuotanto todistaa toisesta asenteesta, jossa varsin tarkat analyysit ja kuvaukset valaisevat älyn ja elämän vuorovaikutusta ja siten myös käsitteellisin keinoin edesauttavat ymmärrystä. s

FT JAN-IVAR LINDÉN on Helsingin yliopiston filosofian dosentti ja johtaa Historiallisen ontologian keskusta Heidelbergissä.

\section{VIITTEET}

1 "Peut-être faut-il d'ailleurs qu'une théorie se maintienne exclusivement à un point de vue particulier pour qu'elle reste scientifique, c'est-à-dire pour qu'elle donne aux recherches de détail une direction précise. Mais la réalité sur laquelle chacune de ses théories prend une vue partielle doit les dépasser toutes."

2 "...notre raison aime mieux annoncer une fois pour toutes, avec une orgueilleuse modestie, qu'elle ne connaîtra que $d u$ relatif et que l'absolu n'est pas de son ressort: cette déclaration préliminaire lui permet d'appliquer sans scrupule sa méthode habituelle de penser et, sous prétexte qu'elle ne touche pas à l'absolu, de trancher absolument sur toutes choses."

3 Joskus elämänfilosofiaan liitetään myös joukko sosiaalidarwinisteja kuten Herbert Spencer ja Ernst Haeckl, varsinkin silloin, kun tarkoitus on osoittaa poliittisesti ongelmallisia aspekteja elämänfilosofiassa. Käsite on kuitenkin silloin niin laaja, että sen tarkoituksenmukaisuutta voi hyvin epäillä. Bergsonkirjallisuus on toki mittavaa ja sieltä löytyy joskus myös biologistisia näkemyksiä, varsinkin 1900-luvun alkupuolelta. Näitä paljon kiinnostavimpia ovat kuitenkin varsinaiset filosofiset tulkinnat. Erittäin valaiseva teos Bergsonista on Trotignon 1968. Ks. myös Worms 2004.

4 Kun Descartes joskus käyttää sanontoja, jotka vaikuttavat viittaavan elämään niitä seuraa johdonmukaisesti mekanistinen täsmennys, esimerkiksi teoksessa Sielun liikutukset.

5 Konrad Lorenzilta (Lorenz 1973) alkusysäyksen saanut suuntaus on myöhemmin tuottanut runsaasti kirjallisuutta. Ks. esim. Wuketits 1990. Kriittinen näkökulma löytyy teoksesta Evolutionstheorie und menschliches Selbstverständnis (Spaemann Koslowski \& Löw 1984).

6 Maurice Merleau-Ponty näki myöhemmin nämä yhteydet ja kehitti niitä fenomenologisen käsitteistön avulla, ruumiillisuutta painottaen. Merleau-Pontylle kehosubjekti on yhtä vähän puhdas tietoisuus kartesiolaisessa tai kantilaisessa mielessä kuin tieteellinen objekti. Koskien Maine de Birania ja Bergsonia, ks. Merleau-Ponty 1968.

7 Molemmista teoksista on uusia painoksia. De l'habitude on ilmestynyt myös englanniksi Clare Carlislen \& Mark Sinclairin kääntämänä ja ruotsiksi Jan-Ivar Lindénin kääntämänä.

8 Koskien Maine de Birania ja Ravaissonia, ks. Lindén 2004.

9 Idealismi on tässä teoksessa lähinnä subjektiivista. 
10 Suomeksi on usein hankalaa löytää hyviä käännöksiä Bergsonin ilmaisuille. Jo sana chose on hankala. Kun Bergson kuvaa kritisoimiaan representaatio-teorioita, chose voi olla objekti tai kohde. Jos sen sijaan puhutaan Bergsonin omasta käsityksestä niistä olioista, jotka esiintyvät havaintokentässä, on luontevampaa sanoa joko "olio" tai ehkä "esine". Esinehän on nimenomaan esiintyvä olio. Bergsonin mukaan kohde (objekti) on suppeampi versio esineestä tai oliosta.

11 1600-luvulla voimistunut ajatus siitä, että havainnot ovat jollain tavalla havaitsevan subjektin sisällä ja muodostavat subjektin ja ulkomaailman välille verhon, luo uudelle ajalle tyypillisen ongelman "ulkomaailman" olemassaolosta. Vielä 1900-luvulla tällaiset näkemykset olivat hyvin yleisiä, varsinkin niissä piireissä, joissa keskusteltiin aistimateriasta (sense data) tiedon perustana. Nykyisin näkemyksestä ollaan kuitenkin pitkälti luovuttu. Hyvin erilaiset ajattelijat ovat kritisoineet ideaa tällaisesta maailman kaksinkertaistumisesta havainnossa, Bergsonin lisäksi esimerkiksi William James ja Max Scheler. Max Scheler on erityisen kiinnostava suhteessa Bergsoniin. Ks. Scheler 1960 sekä Scheler 1972.

12 Heideggerin kielteinen suhtautuminen ontologiaan, joka korostaa läsnäoloa (Anwesenheit) ja esilläoloa (Vorhandenheit) eroaa kuitenkin Bergsonin käsityksestä. Havainto toimii Bergsonin mukaan kentässä, joka on nimenomaan annettu ja siinä mielessä läsnäoleva. Vrt. Bergson 1990, 32-3.

13 Kts. varsinkin James 1983.

14 L'affection "mesure le pouvoir absorbant du corps" (Bergson 1990, 57).

15 Liikkumisen yhteydestä jakoon ulkoisen ja sisäisen välillä, ks. mt, 45-6.

16 Esimerkiksi mt., 27-9. Syntyy kuitenkin kysymys, tarkoittaako tämä myös sitä, että materia sellaisenaan on yleisesti ottaen määräävä (determinoiva) aines.

17 Edeltävässä ranskalaisessa traditiossa tottumus liittyy läheisesti niihin muistiprosesseihin, jotka edistävät samankaltaisuutta, sekä tilanteiden välillä että ajallisesti samanlaisina toistuvina mekanismeina.

18 "Je passe mes diverses affections en revue: il me semble que chacune d'elles contient à sa manière une invitation à agir, avec, en même temps, l'autorisation d'attendre et même de ne rien faire.” (Bergson 1990, 12.)

19 Esim. Bachelard 1993a ja Bachelard 1993b. Vrt. myös Bachelard 1993c. Yhtäläisyyksistä ja eroavaisuuksista Bachelardin ja Bergsonin välillä, ks. Worms \& Wunenburger 2008.

20 Hartmannin Philosophie des Unbewußten on ensimmäinen osa laajamittaisesta työstä. Teos oli 1800-luvun loppupuolella niin tärkeä, että siitä tehtiin jopa ruotsinkielinen käännös, Hartmann
1877-78. Caruksen tärkein teos on Psyche. Zur Entwicklungsgeschichte der Seele (Carus 1846).

21 Näin esimerkiksi L'évolution créatrice -teoksen neljännessä luvussa.

22 Platonismi on Bergsonin mukaan jopa älyn luontainen suuntaus ("Nous naissons tout platonciens", Bergson 1994, 49), mutta filosofian rooli on hänelle nimenomaan toimia tämän idealisoivan tendenssin vastavirtana.

23 Immanuel Kantin kautta tunnettu jako sisäisen ja ulkoisen tarkoitusmukaisuuden välillä (innere und äußere Zweckmäßigkeit, Kant 1974, varsinkin SS 61-8) on Bergsonin mukaan harhaanjohtava. Sisäinen teleologia, jonka avulla on yritetty säilyttää teleologinen periaate, vaikkapa siten kuin se ilmenee organismin tarkoituksenmukaisuudessa, merkitsee Bergsonin mukaan kuitenkin organismin tapauksessa esimerkiksi soluille ulkoista päämäärää, koska organismi on eri asia kuin solu. Tähän liittyy myös ongelmallinen kysymys yksilön rajoista. Jos teleologinen kausaalivaikutus on olemassa, kyse on aina ulkoisesta teleologiasta, mutta Bergsonin mukaan teleologinen tarkoituksenmukaisuus, samoin kuin mekanismi, perustuu inhimillisen pragmatiikan projisointiin (Bergson 1994, 41-4).

24 Darwin ja darwinismin valtavirta korostavat organismeja, Richard Dawkins mikrotasoa (Dawkins 2006), Vero C. Wynne-Edwards joukkovalintaa (WynneEdwards 1986). Rupert Sheldrake korostaa vielä radikaalimmin kuin Wynne-Edwards yksilöitä ylittävää tasoa (morfinen kenttä, jolle yksilö on altis). Tässä ei kuitenkaan ole kyse bergsonismin myöhäisestä versiosta, vaan dispositioita korostavasta teoriasta, joka ei ole sopusoinnussa Bergsonin keskeisen idean eli jatkuvan luovuuden kanssa (Sheldrake 1989).

25 Laplace muotoilee tämän determinismin varsin selvästi: "Äly, joka tiettynä ajankohtana tunnistaisi kaikki luonnonvoimat ja niiden olioiden eri tilat, jotka muodostavat tämän luonnon, kattaisi - mikäli se muuten olisi tarpeeksi laaja analysoidakseen nämä tosiseikat - samassa lausekkeessa maailmankaikkeuden suurimpien kappaleiden ja kevyimmän atomin liikkeet: mikään ei olisi tälle älylle epävarmaa ja menneisyys samoin kuin tulevaisuus olisi sille näkyvissä läsnäolevana." (Une intelligence qui, pour un instant donné, connaitrait toutes les forces dont la nature est animée et la situation respective des êtres qui la composent, si d'ailleurs elle était assez vaste pour soumettre ces données à l'analyse, embrasserait dans la même formule les mouvements des plus grands corps de l'univers et ceux du plus léger atome: rien ne serait incertain pour elle, et l'avenir, comme le passé, serait présent à ses yeux.) Laplace 1886, s. VI (viite Bergsonin mukaan, Bergson 1994, 38). Vrt. myös mt., 45. 
26 Jo L'évolution créatrice -teoksen ensimmäinen lause ilmaisee miksi luonto elämänfilosofiassa ymmärretään inhimillisen kokemuksen kautta: "Olemassaolo, joka on meille vakuuttavin, ja jonka tunnemme parhaiten, on kiistämättä meidän oma olemassaolomme..." (L'existence dont nous sommes les plus assurées et que nous connaissons le mieux est incontestablement la nôtre...)

27 Älyn keskeinen rooli on "valaista käyttäytymistämme" (a pour fonction essentielle d'éclairer notre conduite, Bergson 1994, 29).

28 Tässä yhteydessä Bergson erottelee kolme kausaliteetin muotoa: työntö (billiardipallon tapainen impulsion), laukaisu (esimerkiksi räjähdystä aiheuttava déclenchement) ja jatkuva vaikutus (pyörivän äänilevyn tapainen jatkuva deroulement). Bergson 1994, 73-4.

30 "Le principe du mécanisme est que 'les mêmes causes produisent les mêmes effets.” Mt., 57 . Vrt. myös mt., 29, 57 sekä seuraava älyn määrittely: "l'intelligence, faculté de lier le même au même”, mt., 52.

31 Durée on Bergsonille alati muuttuva, ei samanlaisena pysyvä kesto. Tämä käsitys jatkuvuudesta eroaa vanhemman metafysiikan ideasta kestosta, joka on alati sama. Mikäli durée käännetään suomeksi sanalla "kesto", olisi ehkä luontevaa sanoa "jatkuva kesto". Ehdotan tässä käännöksenä jatkumoa.

32 Mt., esim. 90.

33 ”[E]pämääräisen representaation reuna-alueet, jotka ympäröivät tarkan representaatiomme" (la frange de représentation confuse qui entoure notre représentation distincte, mt. 49). Vrt. myös "kattavampi representaatio, josta äly on suppeampi versio" (la représentation plus compréhensive dont l'intelligence n'est que le rétrécissement, mt., 52).

34 Teleologinen tarkoitus olisi silloin implisiittinen päämäärä jo annetussa välineistä kiinnostuneessa kokemuksessa, eikä pragmaattisesti kiinnostavaan ennakointiin liittyvä. Vrt. "finalistinen tulkinta, [...] tietty näkemys menneestä läsnäolevan valossa" (... l'interprétation finaliste, /.../ une certaine vision du passé à la lumière du présent, mt., 52).

\section{KIRJALLISUUS}

Bachelard, Gaston (1993a) La poétique de la rêverie, Presses universitaires de France, Paris

Bachelard, Gaston (1993b) Le droit de rêver, Presses universitaires de France, Paris

Bachelard, Gaston (1993c) La dialectique de la durée, Presses universitaires de France, Paris

Bergson, Henri (1994) L'évolution créatrice, Presses universitaires de France, Paris

Bergson, Henri (1990) Matière et mémoire, Presses universitaires de France, Paris

Carus, Carl Gustav (1846) Psyche. Zur Entwicklungsgeschichte der Seele, Flammer und Hoffmann, Pforzheim

Dawkins, Richard (2006) The Selfish Gene, Oxford University Press, Oxford

Driesch, Hans (1928) Philosophie des Organischen, Quelle \& Meyer, Leipzig

Hartmann, Eduard von (1869) Philosophie des Unbewußten, Berlin, Duncker

Hartmann, Eduard von (1877-78) Verldsprocessens väsen eller Det omedvetnas filosofi (övers. Stuxberg, Anton)

Hegel, G. W. F. (1986) Vorlesungen über die Geschichte der Philosophie, Suhrkamp, Frankfurt am Main

Heidegger, Martin (1986) Sein und Zeit, Niemeyer, Tübingen

James, William (1983), The Principles of Psychology, Harvard University Press, Cambridge Massachusetts \& London

Kant, Immanuel (1974) Kritik der Urteilskraft, Meiner, Hamburg

Laplace, Pierre-Simon de (1886) Introduction à la théorie analytique des probabilités, Oeuvres complètes VII, Paris

Lindén, Jan-Ivar (2004) ”Fin, finitude et désir infini. Quelques remarques sur l'aristotélisme de Ravaisson" teoksessa (Denis Thouard, éd.) Aristote au XIXe siècle, Presses universitaires du Septentrion, Paris

Lorenz, Konrad (1973), Rückseite des Spiegels. Versuch einer Naturgeschichte des menschlichen Erkennens, Piper, München

Merleau-Ponty, Maurice (1968) L'union de l'âme et du corps chez Malebranche, Biran et Bergson. Notes prises au cours de M. Merleau-Ponty à l'École Normale Supérieure (1947-1948), recueillies et rédigées par Jean Deprun, Vrin, Paris

Ravaisson, Félix (1838) De l'habitude, Fournier, Paris

Ravaisson, Félix (1837-46) Essai sur la métaphysique d'Aristote, Imprimerie royale, Paris

Ravaisson, Félix (2008) Of Habit (transl. Carlisle, Clare \& Sinclair, Mark), Continuum, London \& New York

Ravaisson, Félix (2002) Om vanan (övers. Lindén, Jan-Ivar), Eithe, Paris

Scheler, Max (1960) Erkenntnis und Arbeit. Eine Studie über Wert und Grenzen des pragmatischen Motivs in der Erkenntnis der Welt, Klostermann, Frankfurt am Main

Scheler, Max (1972) "Versuche einer Philosophie des Lebens: Nietzsche, Dilthey, Bergson", Gesammelte Schriften III, Francke, Bern 
Sheldrake, Rupert (1989) The Presence of the Past, Fontana, London

Spaemann, Robert, Koslowski, Peter \& Löw, Reinhard (Hg.) (1984) Evolutionstheorie und menschliches Selbstverständnis. Zur philosophischen Kritik eines Paradigmas moderner Wissenschaft, Acta humaniora, Weinheim

Trotignon, Pierre (1968) L'idée de vie chez Bergson et la critique de la métaphysique, Presses universitaires de France, Paris
Worms, Fréderic \& Wunenburger, Jean-Jacques (éd.)

(2008), Bachelard et Bergson. Continuité et discontinuité, Presses universitaires de France, Paris

Worms, Frédérick (2004) Bergson ou les deux sens de la vie, Presses universitaires de France, Paris

Wuketits, Franz (1990) Evolutionary Epistemology and Its Implications for Humankind, State University of New York Press, Albany

Wynne-Edwards, Vero C. (1986) Evolution Through Group Selection, Blackwell, Oxford 